\title{
INEQUALITY OF WAGE RATES, EARNINGS AND FAMILY INCOME IN THE UNITED STATES, 1975-2002
}

\author{
By Peter GottschalK* \\ Boston College \\ AND \\ SHELDON DANZIGER \\ University of Michigan
}

\begin{abstract}
This paper analyzes distributional changes over the last quarter of the twentieth century. We focus on four distinct distributions: the distribution of hourly wage rates, the distribution of annual earnings of individuals, the distribution of annual earnings of families, and the distribution of total family income adjusted for family size. Both male wage rate inequality and family income inequality accelerated during the early 1980s, increased at a slower rate through the early 1990s and then stabilized at a high level through the early 2000s. The similarity in the timing of changes in these two distributions has been used as evidence that increased family income inequality primarily reflects increased inequality of wage rates. We show that other important factors were also at work.
\end{abstract}

\section{INTRODUCTION}

This paper reviews evidence on changes in inequality of four distinct income concepts: individual wage rates, individual annual earnings, family annual earnings, and family income adjusted for family size. The first two income concepts are the primary focus of labor economists. Changes in the distribution of wage rates reflect changes in labor supply and labor demand and changes in labor market institutions, including changes in government policies. Labor economists have spent considerable effort documenting increased inequality in male wage rates and the reasons for these changes, including the importance of technological changes, changes in foreign competition, changes in wage-setting institutions, such as labor unions, and changes in governmental regulations, such as the minimum wage. ${ }^{1}$ While there is still considerable uncertainty about the causes of these changes, there is broad consensus that wage rate inequality is considerably higher at the start of the 21 st century than it was a quarter of a century earlier. ${ }^{2}$ In fact, increases

Note: We thank Darrel Barbatto, Yuanyuan Chen, Petia Petrova, Olga Sorokina and Sisi Zhang for outstanding research assistance. Deborah Reed, participants at the WIDER conference in Helsinki, and anonymous reviewers provided very useful suggestions that improved the paper. This research was supported by funds provided by the Russell Sage Foundation. Peter Gottschalk is Professor of Economics at Boston College. Sheldon Danziger is Henry J. Meyer Collegiate Professor of Public Policy and Co-Director of the National Poverty Center at the University of Michigan.

*Correspondence to: Peter Gottschalk, Professor of Economics, Department of Economics, Boston College, 140 Commonwealth Avenue, Chestnut Hill, Boston, MA 02467, USA (gottscha@bc.edu).

${ }^{1}$ See Katz and Autor (1999) for a broad overview. Katz and Murphy (1992) provide a useful framework used in much of this literature. Card and Dinardo (2002) examine the effects of technological change. Lee (1999) examines the effects of the minimum wage. Johnson and Stafford (1999) review the evidence on the impact of international trade.

${ }^{2}$ See Gottschalk (1997) for an overview. 


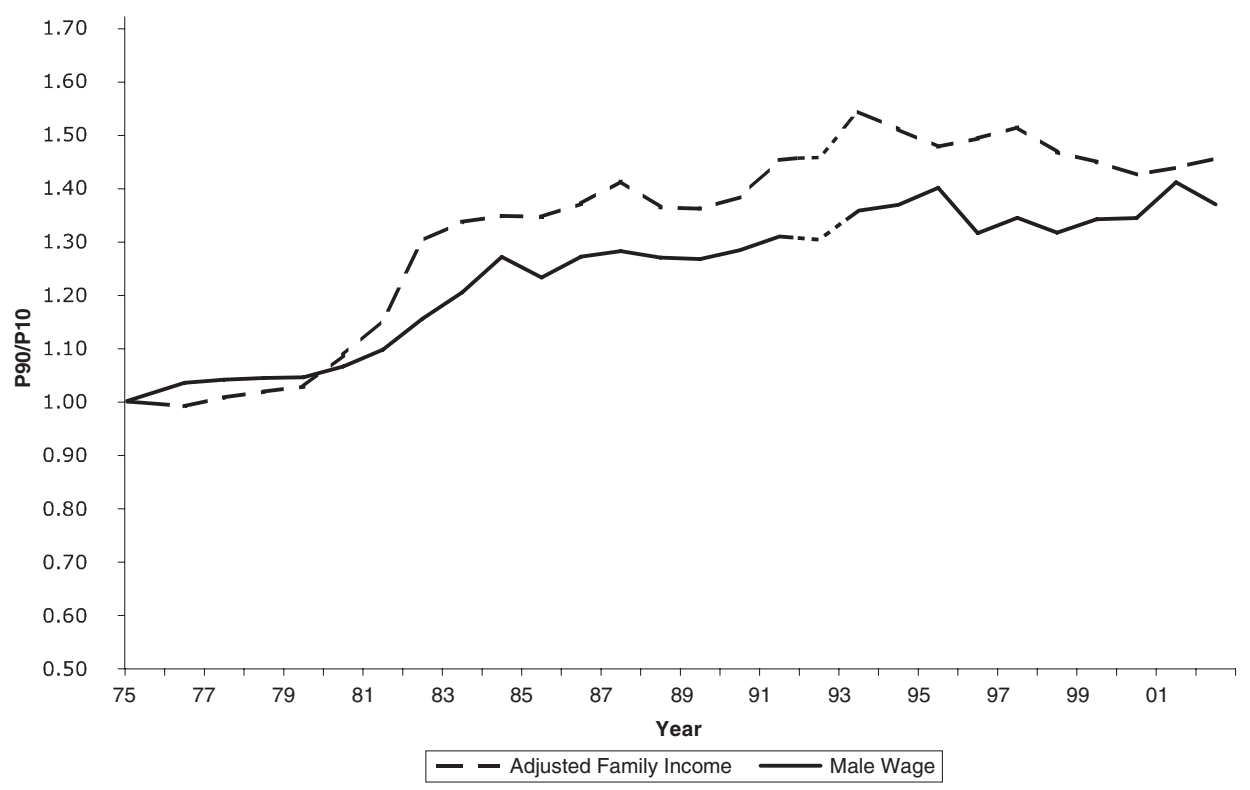

Figure 1. Inequality of Adjusted Family Income and Inequality of Male Hourly Wage Rates, 1975-2002 $(1975=1.0)$

in wage rate and annual earnings inequality occurred primarily in the early 1980s, and were not reversed by a prolonged economic recovery during the 1990s.

Whereas changes in wage rate inequality have been the primary focus of studies by labor economists, changes in family income inequality have been the primary focus of studies by public policy analysts interested in changes in the distribution of well-being and changes in poverty. ${ }^{3}$ Again, there is broad consensus about the facts. Family income inequality increased dramatically during the last quarter of the 21st century. This reflects sharp increases during the late 1970s and early 1980s that were not offset by declines during the long expansion of the 1990s.

Figure 1 shows inequality of hourly wage rates for male workers between the ages of 22 and 62 and inequality of family income (adjusted for family size) for all persons living in families with a head of household in the same age range over the period 1975-2002. ${ }^{4}$ While the exact timing of changes differs slightly, both follow remarkably similar patterns. Male wage rate and family income inequality rose sharply through the mid 1980s, continued to grow at a slower rate through the early 1990s, and then stabilized at a high level through 2002. Both series have a value that was about 37 percent higher in 2002 than in 1975.

The similarity in these trends is consistent with the view that at least some of the same factors were driving increased inequality of both male wage rates and family income. However, the transition from male wage rates to family income involves a set of factors, some associated with the labor market, some not, that also have distributional consequences. This is seen by recognizing that the distri-

${ }^{3}$ For example, see Danziger and Gottschalk (1995) and Burtless and Jencks (2003).

${ }^{4}$ We use the family size specific poverty line to adjust for family size. This is discussed later in the paper. 
bution of family income, $f_{y}\left(Y_{f}\right)$, is linked to the distribution of individual wage rates, $f_{w}\left(W_{i}\right)$, through a set of identities. ${ }^{5}$ The first is that family income, $Y_{f}$, is equal to family earnings, $E_{f}$, plus family non-earned income, $N_{f}$ :

$$
Y_{f}=E_{f}+N_{f}
$$

The second identity defines family earnings as the sum of earnings of all individuals in the family, which in turn depend on the hours, $H_{i}$, and wage rates, $W_{i}$, of each family member, as well as decisions individuals make about marriage and about living with other relatives:

$$
E_{f}=\sum\left(W_{i} H_{i}\right)
$$

The distribution of family income, therefore, depends on the joint distribution of wage rates and hours for all $k$ persons in the family and the distribution of non-earned income ${ }^{6}$ :

$$
f_{y}\left(Y_{f}\right)=g\left(W_{1}, W_{2} \ldots W_{k}, H_{1}, H_{2} \ldots H_{k}, N_{f}\right)
$$

Changes in the marginal distribution of wage rates thus affect both the distribution of annual earnings for the individual and the distribution of family income. However, there are other factors that also affect the distribution of family income.

The first factor is annual hours of work by individuals. Changes in the joint distribution of wage rates and hours determine changes in the distribution of individual earnings. Therefore, changes in hours may reinforce or counter changes in the marginal distribution of wage rates. For example, individuals at the bottom of the wage distribution may have increased their hours more than individuals at the top of the wage distribution. If this were the case, it would imply that increased inequality of wage rates would be larger than increases in the dispersion of individual earnings.

The second link is from the distribution of individual earnings to the distribution of family earnings. Even if inequality in the distribution of individual earnings increases, family earnings inequality might not rise, because family earnings depend on the joint distribution of earnings of all persons in the family. For example, if the wage rates or hours of work of wives increased the most in families headed by males with low earnings, then family earnings inequality would increase less than inequality of male earnings. ${ }^{7}$

This same reasoning can be applied to non-earned income. If changes in government benefits, such as welfare or other income-tested programs, led to a disproportionately small increase in non-earned income for families at the bottom of the family earnings distribution relative to the increase for other families, then family income inequality would increase more than family earnings inequality.

${ }^{5} f_{y}\left(Y_{f}\right)$ can be defined as the distribution of $Y_{f}$ across families, where each family counts once, or across individuals, where each family is weighed by the number of persons in the family. In our empirical work we weight by the number of persons.

${ }^{6}$ The distribution of family income-to-needs ratios would be further affected by the distribution of family size. We ignore this for expositional clarity, though we account for family size differences in our empirical work.

${ }^{7}$ These identities shed no light on the behavioral impact of any of these endogenous variables. For example, changes in the distribution of male wages may cause changes in family formation. The identity simply shows how the net impact of all these behavioral changes lead to changes in family income. 
The objective of this paper is to systematically examine changes in inequality of each of these distributions (wage rates, individual earnings, family earnings and family income) using a consistent set of definitions and samples. While other papers have examined changes in the distribution of each income concept, it is difficult to make comparisons across studies that use different measures or samples.

We start by discussing the measurement issues that guide our analyses. This is followed by a description of changes in inequality of each income source. We conclude by discussing whether the observed increase in family income inequality was largely driven by the widely-documented increase in inequality of male wage rates or whether there were offsetting changes in hours worked by different family members or changes in the distribution of other income sources.

\section{Measurement Issues}

We use the annual March Current Population Surveys (CPS) from 1976 to 2003 to analyze changes in the levels and distributions of individual wage rates and annual earnings, family earnings and family income adjusted for family size. The availability of yearly data allows us to examine cyclical as well as secular changes. ${ }^{8}$ CPS person weights are used throughout. ${ }^{9}$

Our primary sample includes all individuals (except those in the armed forces and those living in group quarters) between the ages of 22 and 62, who had positive weeks of work and positive wage and salary earnings in the calendar year prior to the March interview. ${ }^{10}$ The age restriction is consistent with previous studies that have focused on an age group with strong labor force attachment. The requirement that sample members must have had positive annual earnings further limits the analysis to persons attached to the labor force. ${ }^{11}$ Because studies of family income inequality usually focus on all persons, not just those who are attached to the labor market, we broaden the sample for this income concept to all families headed by individuals between the ages of 22 and 62, including those who have no annual earnings.

To measure family earnings and family income adjusted for family size, we sum the earnings and non-earned income of all related persons (family members)

\footnotetext{
${ }^{8}$ Hourly wage rates are calculated by dividing annual earnings by the product of weeks worked last year and usual hours worked per week last year. This information was first available in the 1976 CPS. The 2003 CPS was the latest available when we conducted our empirical work.

${ }^{9}$ Card and DiNardo (2002) weight by hours worked as well as by the CPS sample weights. We find that this difference in weighting makes very little difference in our results and we prefer to use the distribution across persons rather than the distribution across hours. We also depart from Card and DiNardo (2002) in another respect, as they exclude all observations whose hourly wage is less than $\$ 1$ or greater than $\$ 100$ per hour in 1979 dollars. We do not exclude any one who reports a positive wage rate. Both methods give similar results.

${ }^{10}$ Self-employment income is excluded from the earnings measure. Sample members were also required to have positive potential labor market experience (i.e. age-education- $6>0$ ). These sample definitions are the same as in Card and DiNardo (2002), except that they included persons between the ages of 16 and 64. We restrict the sample to those between the ages of 22 and 62 to focus on those whose labor force attachment is less likely to be affected by schooling and retirement decisions.

${ }^{11}$ Including persons with zero earnings to obtain the unconditional distribution of individual earnings would be straightforward, since they would be entered as zeros. Examination of the unconditional distribution of wages would, however, require that we explicitly model the wages that non-workers would have received.
} 
who reside together. ${ }^{12}$ The Census defines a family as "a group of two or more persons related by birth, marriage or adoption and residing together." 13 We treat unrelated individuals as one-person families. This assumes that the family, not the household, is the income sharing unit..$^{14}$

We adjust family income for family size by dividing family income by the poverty line for that size family. This measure of "income relative to needs" corrects the trend in family income for changes in mean family size over time. The poverty thresholds used to construct the official poverty statistics were set in the early 1960s and are updated annually for price changes using the Consumer Price Index for All Urban Consumers (CPI-U). ${ }^{15}$ According to the Bureau of Labor Statistics (BLS), however, this index would have grown more slowly in the past 35 years if the most recent methods for measuring price changes were applied to the historical data. The BLS produces the Consumer Price Index Research Series (CPI-U-RS) which has the most appropriate adjustments for treating the aging of housing units and the prices of used cars, personal computers and televisions. This measure also accounts for some consumer substitution within CPI item categories. ${ }^{16}$ We, therefore, use this price index to adjust the official poverty thresholds for years after 1969.

We use the ratio of wage rates (or annual earnings or income adjusted by family size) at the 90 th percentile relative to those at the 10 th percentile, P90/P10, as our measure of inequality. This widely-used measure is less sensitive to outliers than other measures, such as the Gini coefficient. It also avoids problems imposed by top coding if top coding only affects those above the 90th percentile. We recognize that when individual components of income, for example earnings and nonearned income, are each top-coded, then the P90/P10 of total income may be affected. We, therefore, also use a procedure described in Burkhauser et al. (2004) to deal with this potential problem.

\footnotetext{
${ }^{12}$ Treating related subfamilies as separate families yields similar results. Family income is defined as the sum of money income from all sources during the calendar year preceding the March CPS. Money income includes wages and salaries, self-employment income, property income (such as interest, dividends, and net rental income), cash transfers from government income maintenance programs and other cash receipts. It does not include capital gains, imputed rents or government or private benefits provided in kind (such as food stamps, Medicare, or employer-provided health insurance), nor does it subtract taxes paid or tax credits received. Greenstein and Shapiro (2003) and Burtless and Jencks (2003) find that inequality of post-tax income as well as pre-tax income grew over the period we study.

${ }^{13}$ We do not sum income across unrelated persons. This is appropriate in many cases. For example, two young adults who happen to share an apartment are not likely to pool their incomes. However, if the two young adults are a cohabiting couple, they would be likely to pool their incomes. Because we cannot distinguish roommates or boarders from cohabiters, we use the Census definition of family. The Census also sums income over all related persons in a unit, even where there is a related subfamily in the unit. For example, if a middle-aged couple has their married daughter and her husband living with them, the Census Bureau pools all of their income and counts them as one family of four persons, not two couples. These Census Bureau procedures differ from those used in official statistics in many European countries.

${ }^{14}$ We also used the household as the income sharing unit, as suggested by Burkhauser et al. (2004), and find that our results are not sensitive to the choice of income sharing unit.

${ }^{15}$ The official poverty thresholds and time series of poverty rates can be found in Current Population Reports, series P-60 or on the Census Bureau website, www.census.gov.

${ }^{16}$ See Stewart and Reed (1999). For more information on the CPI-U-RS, see the BLS website, http://stats.bls.gov/cpi/cpirsdc.htm.
} 


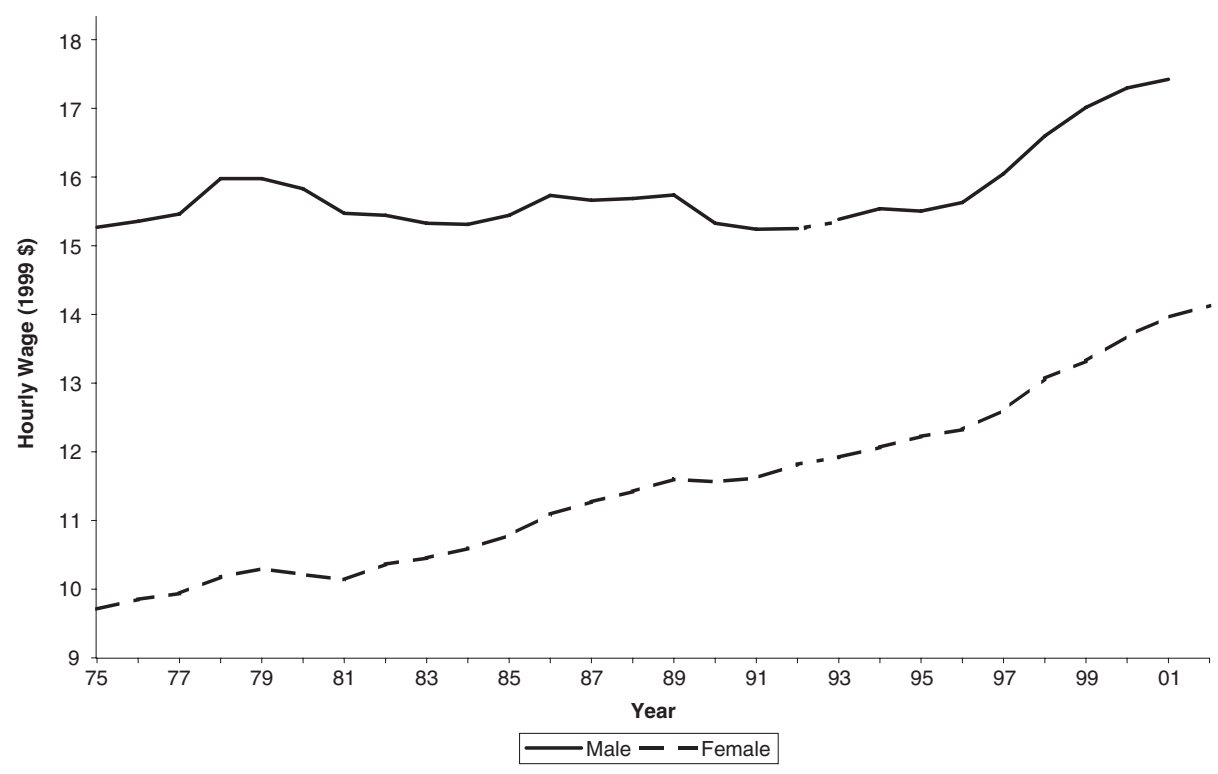

Figure 2. Mean Real Hourly Wage Rate, Males and Females, 1975-2002

All inequality measures are shown for 1975 through 2002. Since the Census Bureau changed its data collection methods between the March 1993 and March 1994 surveys in a way that may have affected measured inequality, we use a dotted line to connect the points between calendar years 1992 and $1993 .{ }^{17}$

\section{Distribution of Individual Wage Rates}

\section{Change in Mean Wage Rate}

Before turning to changes in inequality in the distribution of wage rates, we describe changes in the mean of the distribution. Figure 2 shows mean hourly wages in constant 1999 dollars for male and female workers between the ages of 22 and 62 in each year between 1975 and 2002. For men, the recovery of the 1990s represents a break in the experience of the prior two decades. While male wages increased by 3 percent between 1983 and 1989, those gains were lost during the recession of the early 1990s. The mean hourly wage (in constant 1999 dollars) was virtually the same in 1993 as it had been in 1975 ( $\$ 15.39$ and $\$ 15.28$, respectively). In contrast, between 1993 and 2002, the mean male wage grew by 14 percent to $\$ 17.51$, the first sustained increase in nearly twenty years.

The trend in mean real wages of females over this quarter century is dramatically different from that of men. First, the overall growth rate is much more rapid. Whereas male wages were 15 percent higher in 2002 than they had been in

${ }^{17}$ The 1994 CPS (which gathers information on 1993 earnings and family income) was the first to collect data via computer-assisted interviewing. The Census notes that "one should use caution when comparing estimates from data collected before 1994 with estimates from data collected in 1994 and later." 
1975, female wages were 46 percent higher (\$14.14 vs. \$9.71). Second, while male wages stagnated for most of this period, female wages increased steadily. For example, female wages increased by 15 percent between 1979 and 1989 and by another 15 percent between 1989 and 1999.

\section{Changes in Inequality of Wage Rates}

These trends in mean wages mask different experiences across the distribution of workers. Figure $3 \mathrm{a}$ plots the percentage change in real hourly wages between 1975 and 2002 for males and females at selected percentiles throughout the distribution. This figure shows increased wage inequality for both men and women - the lines slope upward to the right, indicating that percentage changes in wages were higher for workers at the top of the wage rate distribution than for those at the bottom of the distribution.

For men, the relationship between percentile rank and real earnings growth is nearly monotonic - the lower the rank, the smaller the increase (or the larger the decrease) in earnings. At the 10th percentile in 2002, male wages were 2 percent lower than for males at the 10th percentile a quarter century earlier ( $\$ 6.68$ vs. $\$ 6.83$ in $1999 \$)$; the median male had wages that were 4 percent higher $(\$ 15.59$ vs. $\$ 15.00)$. Real wages declined at every point on the distribution up to the 35 th percentile. At the top of the distribution, males at the 95th percentile in 2002 had wages that were 47 percent higher than their counterparts in 1975 (\$48.12 vs. \$32.84). The increased wage inequality over this quarter century reflected an absolute, as well as a relative, decline at the lower end of the distribution. For male workers, the P90/P10 ratio of wage rates increased from 3.9 to 5.3 between 1975 and 2002.

For females, wage inequality also increased, even though real wages increased throughout the distribution. Growth was highest at the higher deciles and lowest

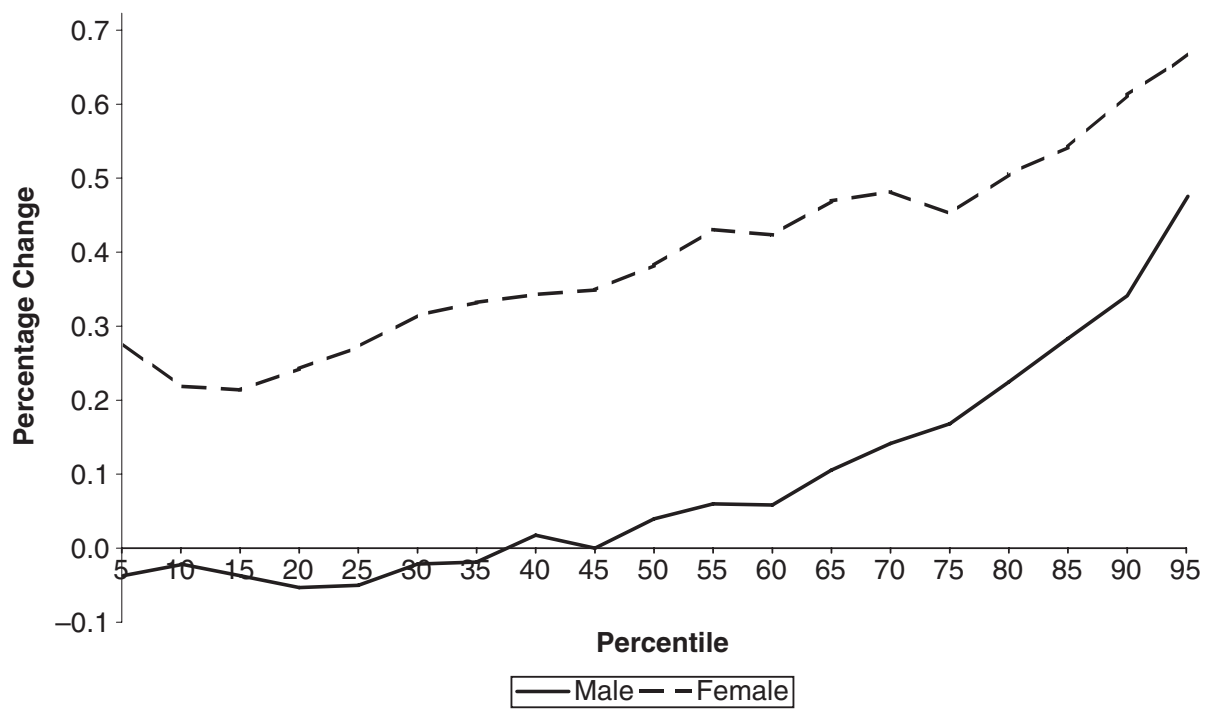

Figure 3a. Percentage Change in Real Hourly Wages by Percentile, 1975-2002 
at the lower deciles. For example, between 1975 and 2002, wages increased by 67 percent at the 95th percentile (from $\$ 20.22$ to $\$ 33.67$ ), by 38 percent at the median (from $\$ 8.80$ to $\$ 12.16$ ), and by 22 percent at the 10th percentile (from $\$ 4.442$ to $\$ 5.42$ ). For female workers, the P90/P10 ratio of wage rates increased from 3.7 to 4.9 between 1975 and 2002 .

Figures $3 \mathrm{~b}$ and $3 \mathrm{c}$ show the same information as Figure $3 \mathrm{a}$, but present data on wage rate changes for the 1982-1989 and 1993-2000 economic recoveries. Each figure depicts wage growth from the trough year to the peak year of the business cycle. The patterns for the 1990 s recovery are strikingly different from those of the 1980s. First, the curves for both males and females in Figure 3c are above 9 percent at all points in the wage distribution. In contrast, wage increases in Figure $3 \mathrm{~b}$ were only 5 percent at the 95 th percentile of males in the 1980s recovery and were negative or close to zero for all workers up to the 80th percentile. For women, wages grew at most points in the distribution during the 1980s recovery, but the rate of increase was much higher for the bottom half during the 1990s expansion.

There are also striking differences in the slopes of the two lines. The lines in Figure $3 c$ are flatter than those in Figure 3b, indicating that wage growth was spread much more evenly throughout the distribution in the most recent economic boom than it was during the 1980s recovery. For females in the boom of the1990s, wage growth was between 10 and 15 percent between the 10 th and 80 th percentile. For males during that recovery, wages rose most at the bottom and at the top of the distribution - by 22 percent at the 5th percentile, from $\$ 4.19$ to $\$ 5.12$, and by 27 percent at the 95th percentile, from $\$ 36.56$ to $\$ 46.47$. Wage growth was between 9 and 17 percent from the 10th through the 90th percentile.

To explore how recessions and recoveries differentially affect wage rate inequality, we show the time series for the P90/P10 ratios in Figure 4. To make the series for males and females comparable we index both to equal 1.00 in 1975 . The ratio for men increased most rapidly during the recession of the early 1980s, rising from 4.1 in 1979 to 4.7 in 1983, but it did not decline during the subsequent recovery, remaining between 4.8 and 5.0 for the rest of the $1980 \mathrm{~s}$. The increase from 5.0 to 5.3 during the recession of the early 1990 s does not differ much from the increase during the recovery of the 1980s, and part of this increase could be due to changes in the CPS procedures. There was a slight decline in the ratio during the later part of the recovery of the 1990s, but an increase to an historic peak at 5.5 as the economy went into recession in 2001 .

The P90/P10 series for women's hourly wage rate shows less cyclicality than the series for men, as the ratio increased steadily from 3.8 to 4.9 between 1975 and 2002. Most of the increased wage inequality occurred during the 1980s.

We distinguish between cyclical and secular changes in wage inequality by plotting the P90/P10 ratio of male wages against the employment rate for males over the age of 20 in Figure 5. During a recession, the economy contracts and the employment rate tends to fall, so a movement to the left indicates a recession; a movement to the right indicates a recovery. If wage inequality is affected by the business cycle, then decreases in employment rates will be accompanied by increased inequality, so the line would be upward sloping. Secular increases in wage inequality are reflected in upward shifts in the line, indicating that inequality is higher even when the employment rate remains constant. 


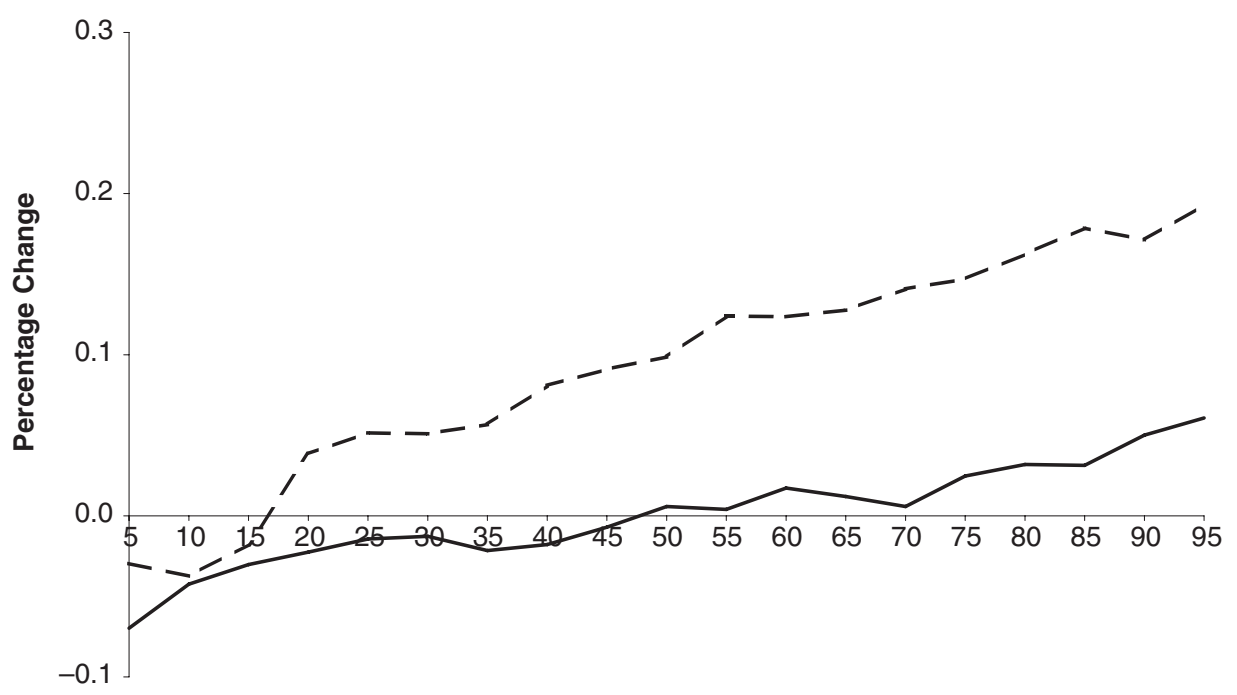

Percentile

Male--Female

Figure 3b. Percentage Change in Real Hourly Wages by Percentile, 1982-1989

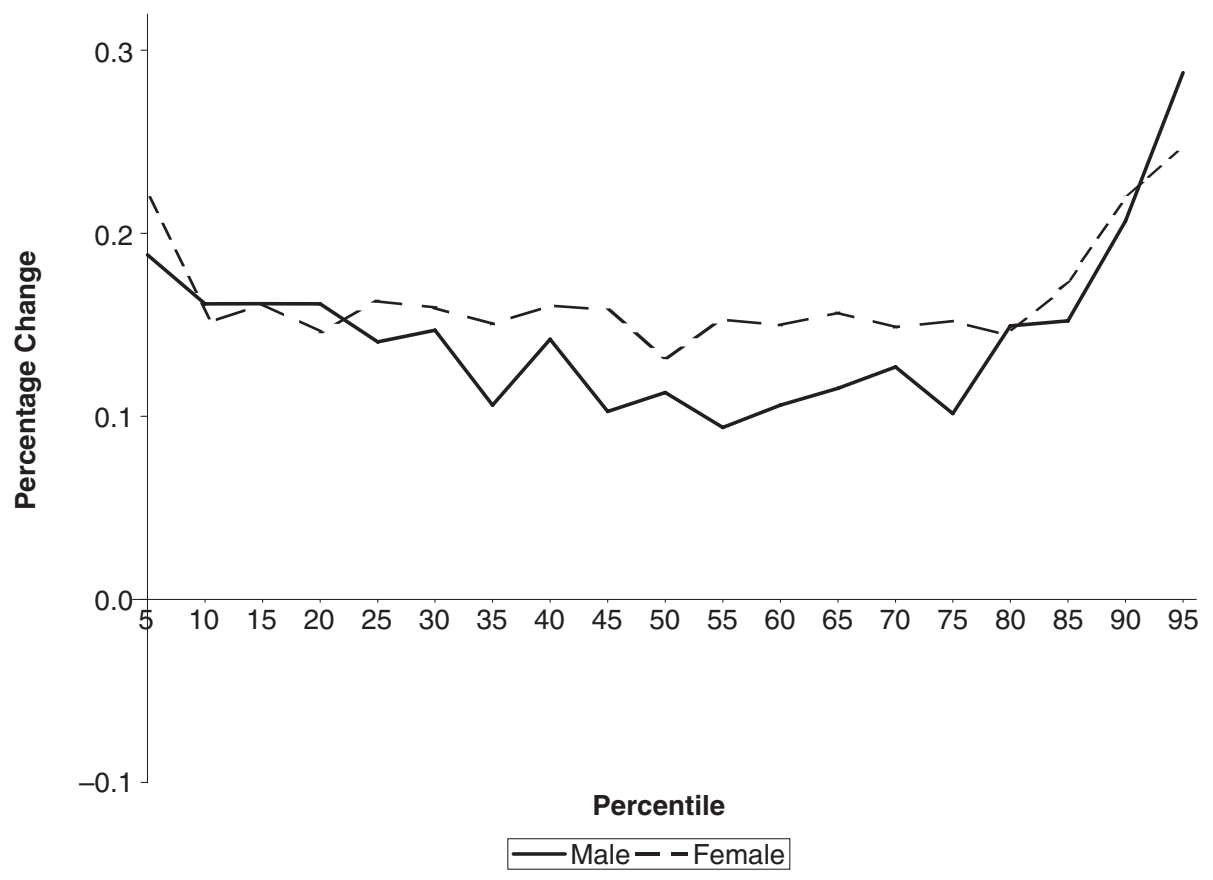

Figure 3c. Percentage Change in Real Hourly Wages by Percentile, 1993-2000 


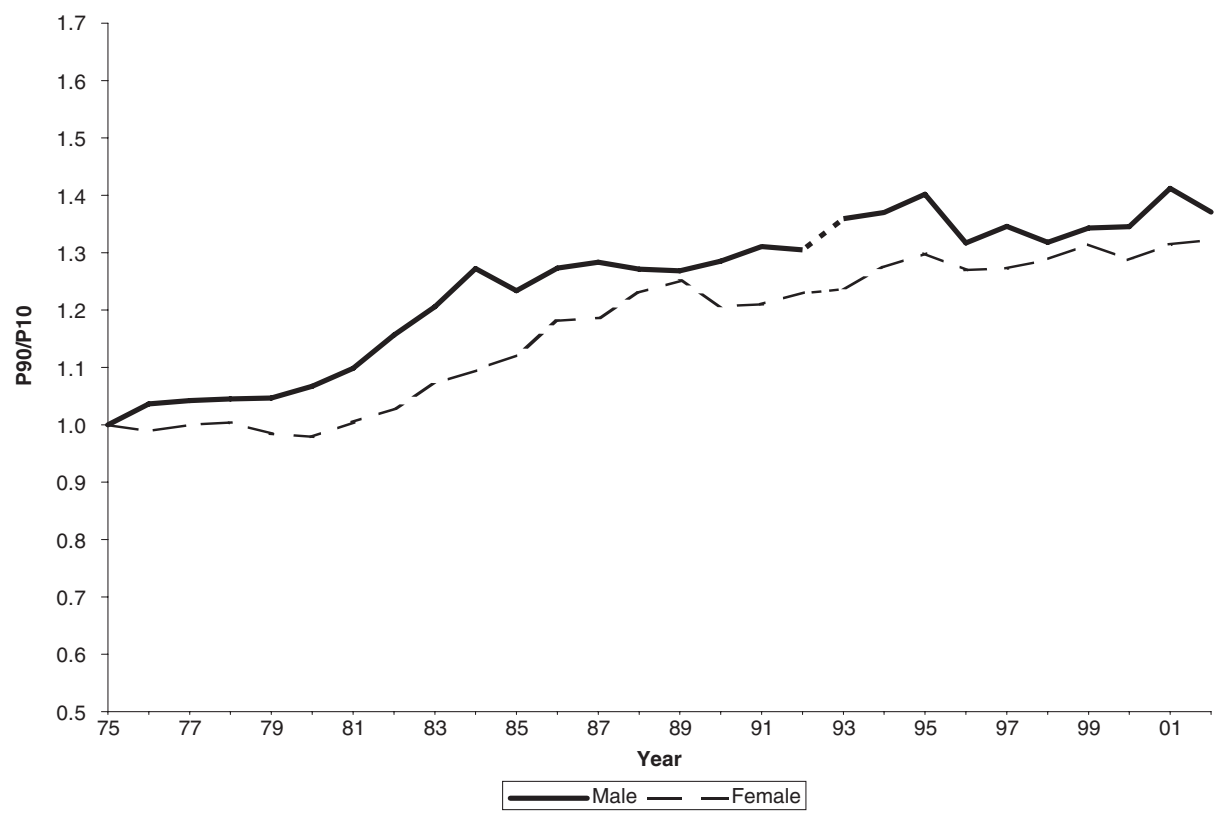

Figure 4. P90/P10 of Hourly Wage Rates $(1975=1.0)$

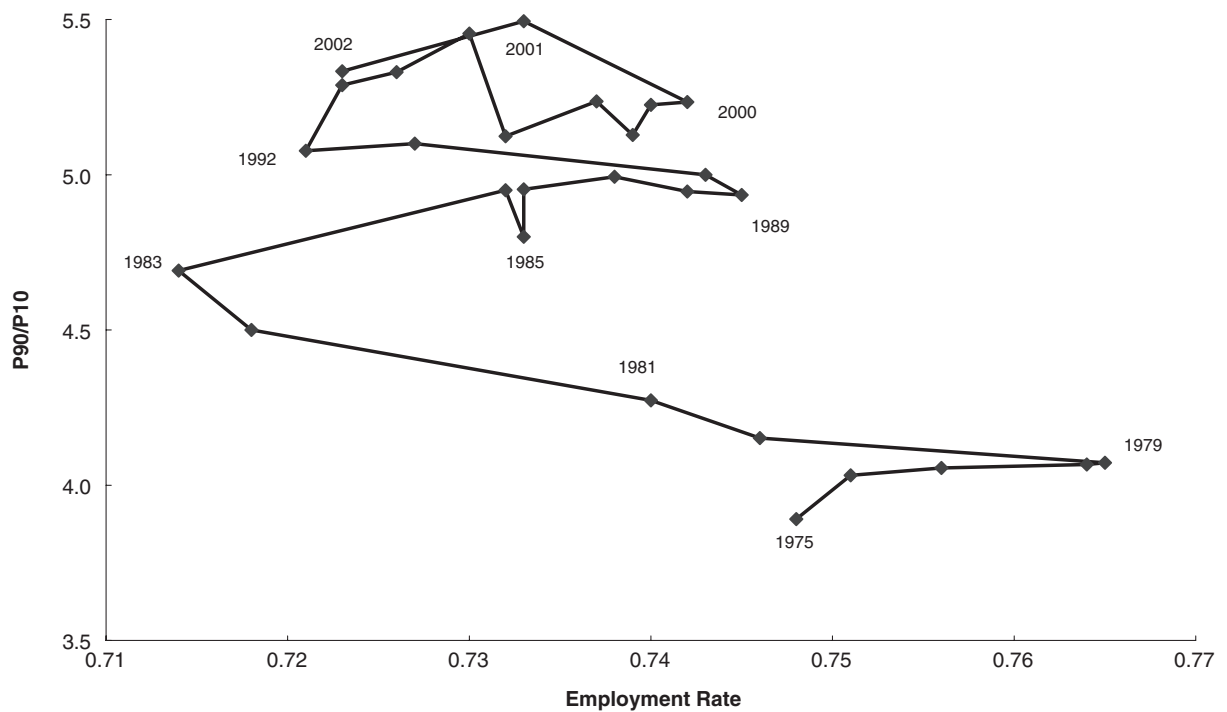

Figure 5. Employment Rate and P90/P10 of Hourly Wage Rate-Males, 1975-2002

Figure 5 highlights several cyclical changes and secular trends. From 1975 to 1979, the male employment rate increased from 74.8 to 76.5 percent (the high point during this quarter century) and the P90/P10 ratio increased from 3.9 to 4.1 . This inequality increase does not reflect a cyclical change since it occurred during an 
expansion. The period from 1980 to 1983 was marked by two recessions. The employment rate fell by 5.1 points between 1979 and 1983 (the low point during this quarter century, 71.4 percent), and the P90/P10 reflects a cyclical increase of an additional 0.6 points to 4.7 . The employment rate increased by 3.1 points during the 1983-1989 recovery, but was accompanied by another secular 0.2 point increase in the ratio to 4.9. The fact that wage inequality failed to decline during the expansion indicates that the large change in wage inequality during the early1980s was not solely a cyclical change.

During the recession of the early 1990s, the employment rate fell again, but the P90/P10 ratio did not increase by much. There was a 0.3 point increase in wage inequality between 1992 and 1993, but this coincides with the change in CPS data collection methods. Thus, one cannot tell how much of this was due to economic changes compared to changes in measurement procedures. By the end of the 1990s expansion, the employment rate had increased back to about the same level as at the end of the 1980s expansion (74 percent). This expansion did not produce a significant decline in wage inequality (the ratio was 5.3 in 1993 and 5.2 in 2000 ), but lack of change was better than the increased inequality of the 1980s expansion.

Over the quarter century, about half of the increased male wage inequality occurred during the 1980s. Inequality increased most during the recession of the early 1980s, but did not decline in any subsequent expansion. We conclude that increases in wage rate inequality primarily reflect long-run secular changes in how labor markets operate, not cyclical fluctuations.

\section{Changes in Between-Group Inequality}

The increased wage inequality we have documented reflects changes in inequality both between groups of workers and within groups. To explore these differences, we estimated a set of standard log wage rate equations, where the independent variables include a set of education dummies (completed less than high school, some college, college, more than college), a quadratic in experience, a gender dummy, dummies for race and ethnicity and three regional dummies (Midwest, South and West). These regressions were estimated separately for each year from 1975 to 2002. (Results are available from the authors.)

From these regressions, we estimate gender and race differentials, holding education and experience constant, and we estimate returns to education and experience, holding other factors constant. Within-group inequality is the remaining variation in wage rates holding all factors constant and is measured by the standard deviation of the residuals.

As shown earlier, mean wage rates for females grew faster than those of males over the entire quarter century. As a result, the between-gender wage rate gap declined. This was partially due to increases in human capital of working women, reflected in their increased education and labor force experience, but it also reflects the increased relative wages of women, holding these characteristics constant. The coefficient on the female dummy variable shows that the gender wage gap closed steadily from 47 percent in 1975 to 27 percent in 1993. 


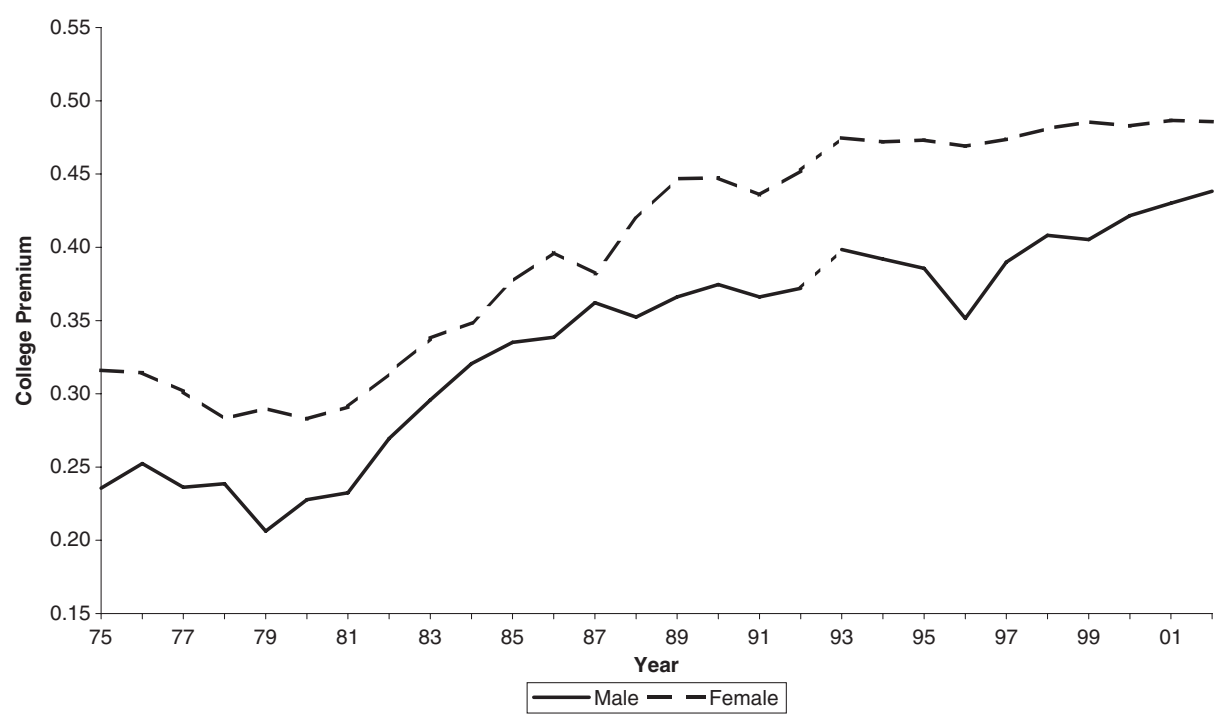

Figure 6. College Graduate-High School Graduate Differential in Hourly Wage Rate, 1975-2002

This decline in the female/male wage rate differential halted after 1993, when real wages of men began to increase after almost 20 years of stagnation. As a result, the gender wage gap was about the same in 2002, 25 percent, as it had been at the start of the 1990s expansion.

Holding personal characteristics constant, there was little change in the black/white male and the black/white female wage differentials over the quarter century. The female gap by race had virtually closed by the mid-1970s, before increasing to 7 percent in 1993. It then fell during the 1990 s recovery to 4 percent in 2002.

The black/white male wage gap is much greater than that for females in every year. It increased from 14 percent in 1975 to about 20 percent during the recession of the early 1980s; then fell to 13 percent in 1996 before rising to 15 percent in 2002. Over this quarter century there was no reduction in the racial wage gaps for men or for women. ${ }^{18}$

The increased wage inequality of the 1980s reflected a substantial increase in the returns to education and to a lesser degree an increase in the returns to experience among young college-educated males. Figure 6 shows the returns to a college degree relative to a high school degree for male and female workers between the ages of 22 and 62. The college premium fell by a few percentage points between 1975 and 1979 for both men and women, before rising dramatically in the 1980s. Between 1979 and 1989 the mean wage rates of college graduates relative to high

\footnotetext{
${ }^{18}$ While we can not compute hourly wage rates prior to 1975 , Gottschalk (1997) reports that the black non-black gap in earnings for full-time workers declined by 2.1 percentage points per year from the mid-1960s to the mid-1970s. This is greater than the 0.4 points per year decline in the black white wage gap reported here. The difference is due, in part, to the greater cyclicality of black work hours relative to white hours. The black/non-black gap in full-time earnings declined from 40 percent in 1963 to less than 15 percent in 1975.
} 


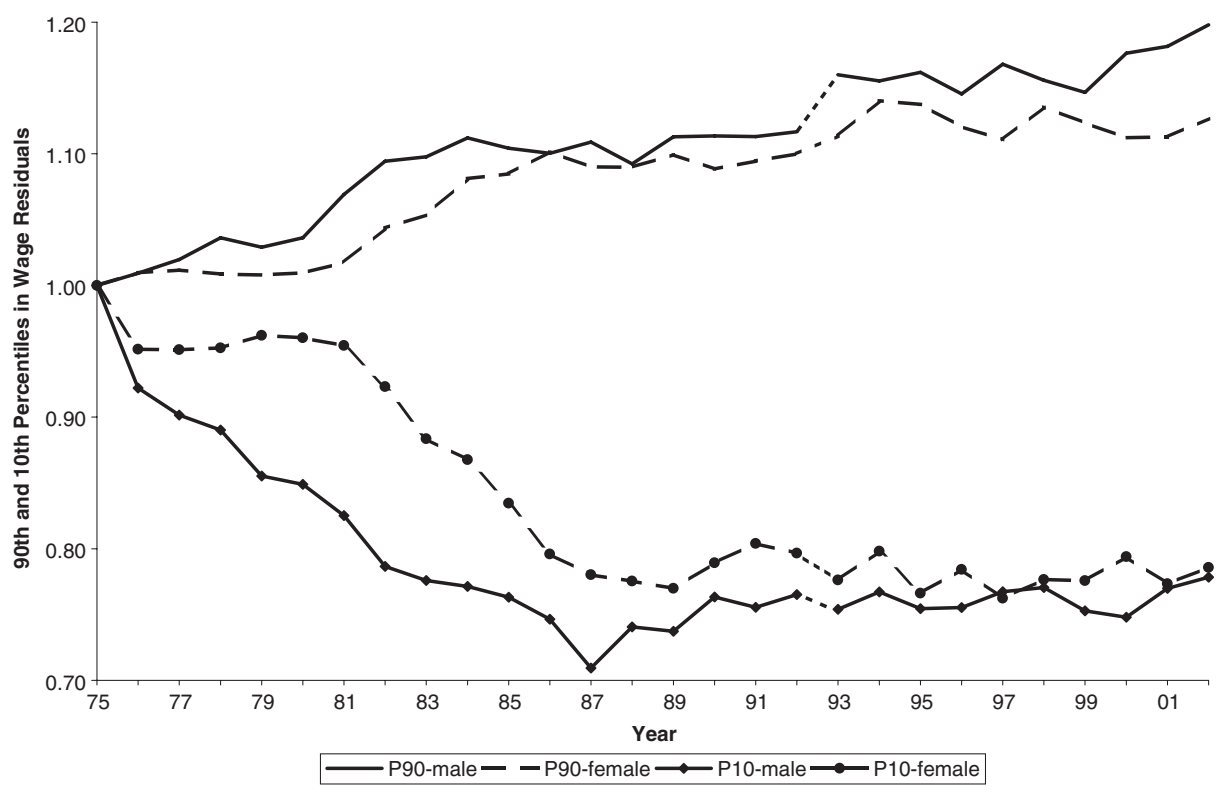

Figure 7. Residual Wage Inequality: 90th and 10th percentiles in Hourly Wages $(1975=1.0)$

school graduates increased from 21 to 35 percent for males and from 29 to 45 percent for females. These premia rose, but at a slower rate through the end of the sample period, reaching 44 percent for males and 49 percent for females in 2002. Thus, one factor that accounted for a large portion of the rising inequality of the 1980s, the college premium, was exerting less upward pressure during the 1990s.

\section{Changes in Within-Group Inequality}

Wage inequality increased during the 1980s, not only among those with different observable traits, such as gender, race, education and experience, but also within groups of workers with the same gender, race, education and experience. ${ }^{19}$ In terms of the regression framework, the growth in within-group inequality is reflected by a wider dispersion of the residuals. Figure 7 plots the P10 and P90 of residual hourly wages for males and females. Each is benchmarked to equal 1.00 in 1975, expressing changes relative to this baseline value.

The patterns are striking. For men and women at the bottom of the distribution, wage rates fell continuously from 1975 through the late-1980s, at which point a male at the 10th percentile had earnings roughly 30 percent lower than a similar worker at the 10th percentile in 1975; for women, the decline was about 25 percent. The $\mathrm{P} 10$ of the residuals then stabilized, remaining relatively constant for both men and women throughout the 1990s, with the value in 2002 about 20 percent lower than in 1975 for both genders.

${ }^{19}$ Lemieux (2004) finds that part of the patterns in within-group inequality in the March CPS is a result of changes in the composition of workers and measurement error. 
In contrast, residual wages at the 90th percentile, increased from 1975 through the mid-1980s, at which time the P90 was roughly 10 percent higher for both males and females than in 1975. The relative positions of males and females then stabilized, rising only between 1992 and 1993, which coincides with the change in CPS procedures. This indicates that within-group inequality among people with the same characteristics stopped increasing until the end of the 1990s, when the P90 for males increased substantially from 1.15 to 1.20 between 1999 and 2002 .

\section{Changes in Individual Earnings Inequality}

Labor economists focus primarily on the distribution of wage rates, as we have done thus far, as these changes in prices reflect changes in demand, supply and/or institutional wage setting mechanisms. We are, however, also interested in changes in the distribution of annual earnings, as this provides a key link between labor market outcomes and the distribution of family income.

Annual earnings for any individual is by definition equal to the hourly wage rate times annual hours worked. Changes in either component will affect annual earnings inequality. ${ }^{20}$ If annual hours increase the most for those with the highest wages, then changes in hours reinforce the inequality-increasing effects of the wage rate changes discussed above and earnings inequality will increase more than wage inequality. If, however, low wage earners increase their hours of work to offset their real wage losses and maintain their living standards (assuming that employers are willing to give them additional hours), then earnings inequality will not increase as much as wage inequality.

Figure 8 presents hours worked by males at the P10 and at the P90 of the male wage distribution. Hours are indexed to 1.00 in 1975 . The increase in hours over the full period 1975 to 2002 for males at the top of the wage distribution was slightly larger than the increase in hours for males at the bottom of the wage distribution. While this secular change in hours would tend to make earnings inequality rise faster than wage inequality, the effect is likely to be small given the small change in hours.

There is, however, substantial cyclical change in the hours of males at the P10 of the wage distribution. Hours for these males fell by 10 percent between 1975 and 1983. This ground was made up during the expansion of the1980s. The recession of the early 1990s again reduced the hours of low wage males by roughly 10 percent. This decline was more than offset by the increase in hours during the sustained expansion during the rest of the 1990s. In contrast, the hours of males at the 90th percentile show little cyclical change. These patterns in hours show that earnings inequality is more cyclically sensitive than wage inequality.

This is confirmed in Figure 9 which shows the P90/P10 for male wage rates and male annual earnings. Inequality of male wage rates and male earnings both increased by 37 percent between 1975 and 2002 so secular changes in hours, which affect earnings inequality, had little impact. Figure 9 confirms that the decline in

\footnotetext{
${ }^{20}$ While inequality measures such as the variance of log earnings can be decomposed into changes in the variances of wages and of hours plus the covariance, the P90/P10 cannot be similarly decomposed.
} 


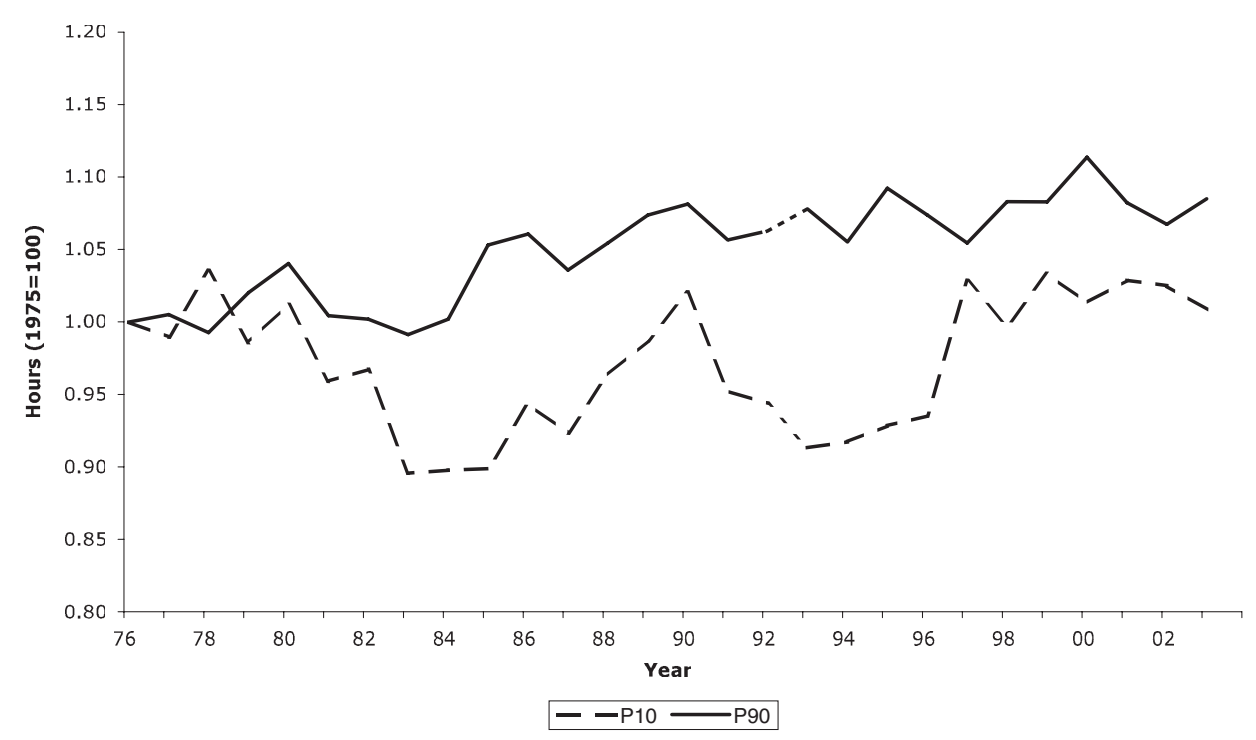

Figure 8. Hours Worked by Males at the P10 and P90 of the Wage Distribution $(1975=1.0)$

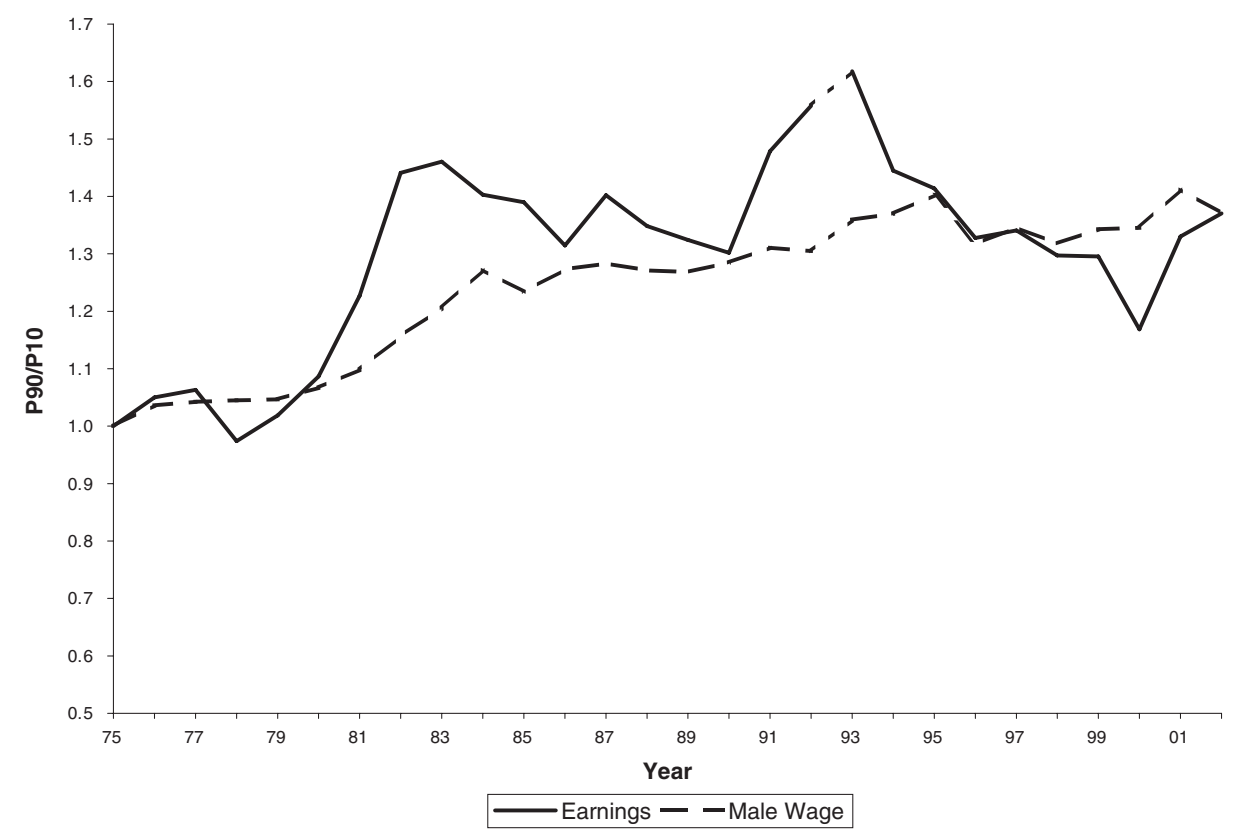

Figure 9. P90/P10 of Annual Earnings and Hourly Wage for Males $(1975=1.0)$ 


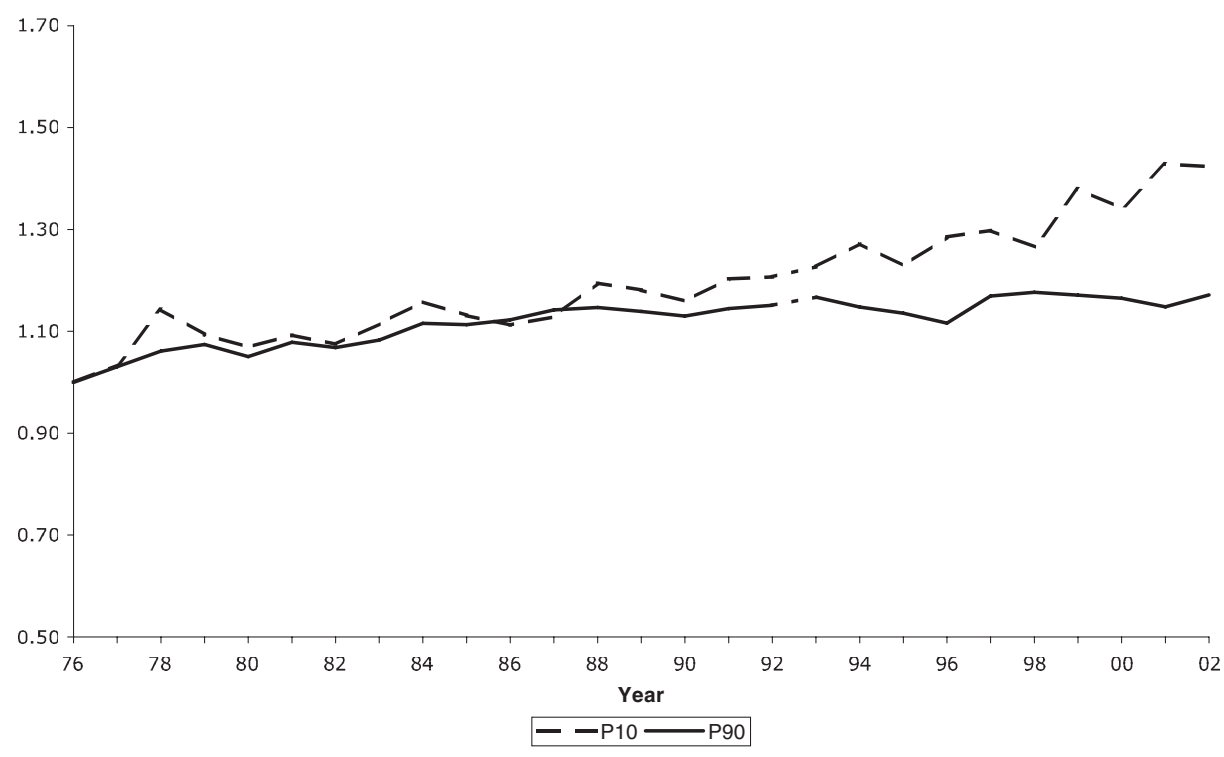

Figure 10. Hours Worked by Females at the P10 and P90 of the Wage Distribution $(1975=1.0)$

hours of males at the P10 during recessions and the increase in hours during expansions led to much larger cyclical swings in earnings inequality than in wage inequality.

The pattern of hours and earnings inequality for females, shown in Figures 10 and 11 , are strikingly different than the patterns for males. Note that hours of females are not cyclically sensitive. Neither females at the P90 nor at the P10 of the wage distribution show cyclical changes in hours. This is in sharp contrast to males at the bottom of the distribution who show strong cyclical changes in hours.

Secular patterns in hours for females are also different than for males. Figure 10 shows that females at the P10 of the wage distribution increased their hours considerably more than females at the P90. Between 1975 and 2002, females at the P10 increased their hours by 47 percent, from 1127 to 1662, while females at the P90 increased their hours by only 18 percent, from 1625 to 1916.

The larger increase in hours at the bottom of the distribution than at the top led to a sharp decline in earnings inequality among females even though wage inequality increased. This is seen in Figure 11 which shows that earnings inequality declined by 37 percent between 1975 and 2002, even though wage rate inequality increased by 32 percent.

In summary, changes in hours had substantial impacts on the trend in earnings inequality. While male wage and earnings inequality have similar trends, they differ sharply over the business cycle, due to cyclical sensitivity of hours for males at the bottom of the distribution. Females do not exhibit this cyclical sensitivity in hours but the trends in wage inequality and earnings inequality differ sharply. The large increase in hours for females at the bottom of the distribution is more than enough to offset the increase in wage inequality. 


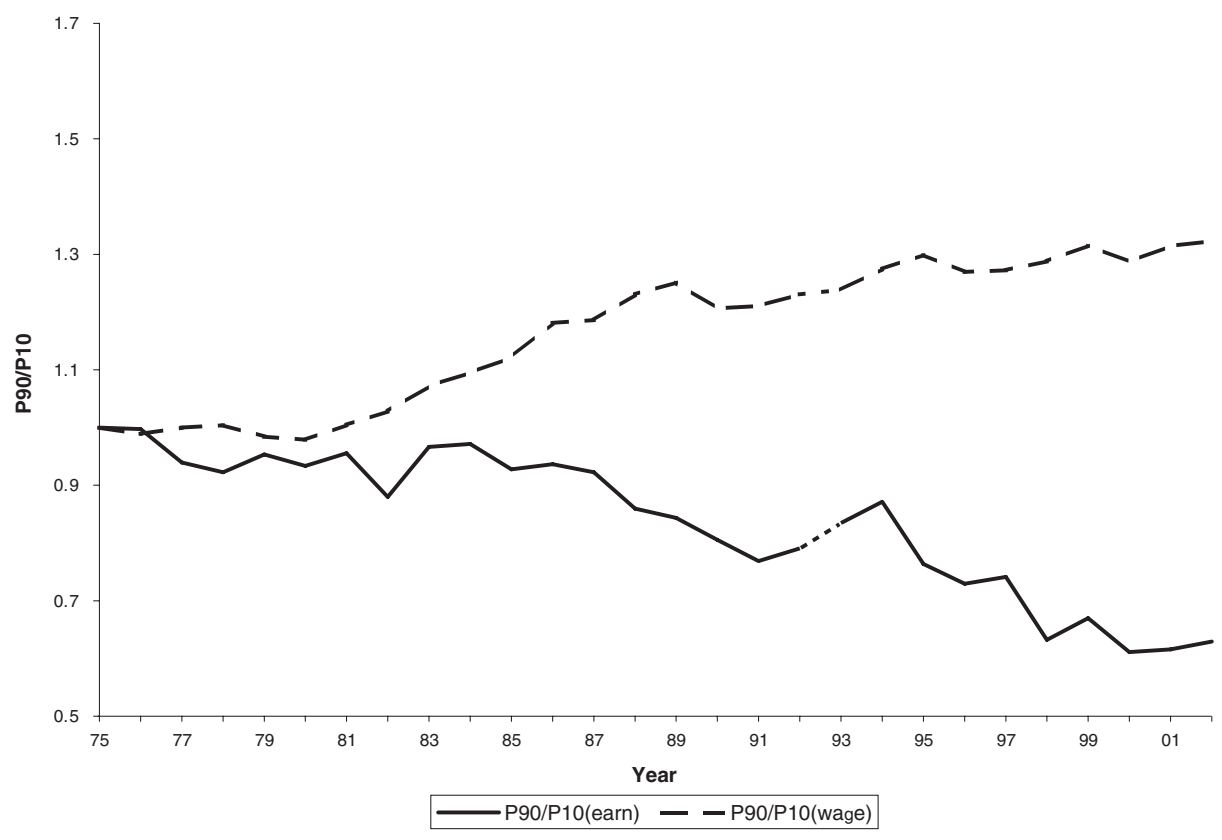

Figure 11. P90/P10 of Annual Earnings and Hourly Wage for Females (1975 = 1.0)

\section{Changes in Family Earnings Inequality}

We now make the transition from the distributions of annual earnings of male and female workers to the distribution of family earnings. Because family earnings is the sum of earnings of all related individuals, family earnings inequality need not change in the same direction as individual earnings inequality. The trend in family earnings inequality will depend on changes in family labor supply across the distribution of individual earners and the correlation of earnings among family members. For example, if males with high earnings have become more likely to marry females with high earnings, or if the wives of high earner males are more likely to enter the labor market, then the resulting increase in the correlation of earnings among family members would by itself increase family earnings inequality. ${ }^{21}$

We now turn to the P90/P10 of family earnings for the same sample of male and female workers used thus far. Instead of ranking individuals by their own individual earnings we rank them by the total earnings of all persons in their families. ${ }^{22}$ Thus, a male with low individual earnings might be in a family with high family earnings if there were a large number of workers in the family or if other persons in the family had high earnings. In order to see the effect of changing the

${ }^{21}$ Cancian and Reed (1999) discuss the impact of wives' earnings on family income inequality.

${ }^{22}$ We attach the total earnings of all persons in the family, regardless of age, to each person in the family. We then select persons who meet our sample restriction (22 to 62 year old with earnings) and use these persons to find the P90/P10 of family earnings. 


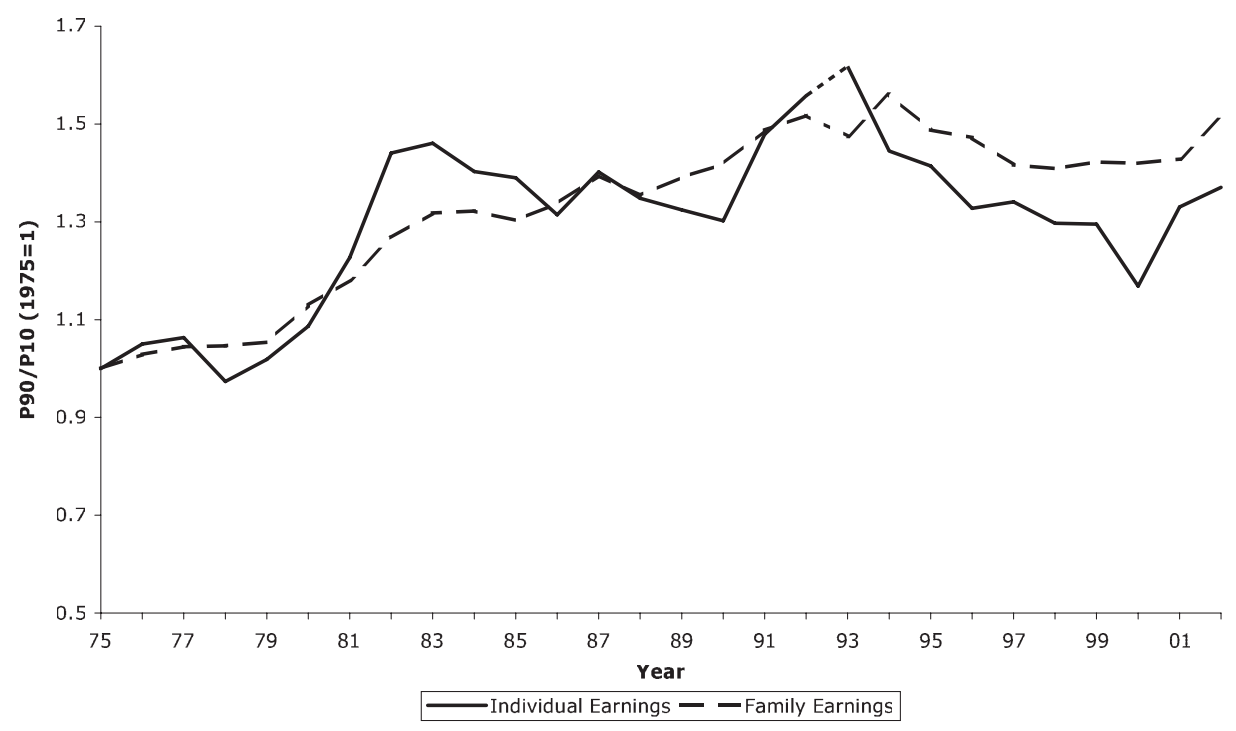

Figure 12. P90/P10 of Individual and Family Earnings: Males 22-62 with Positive Earnings $(1975=1.0)$

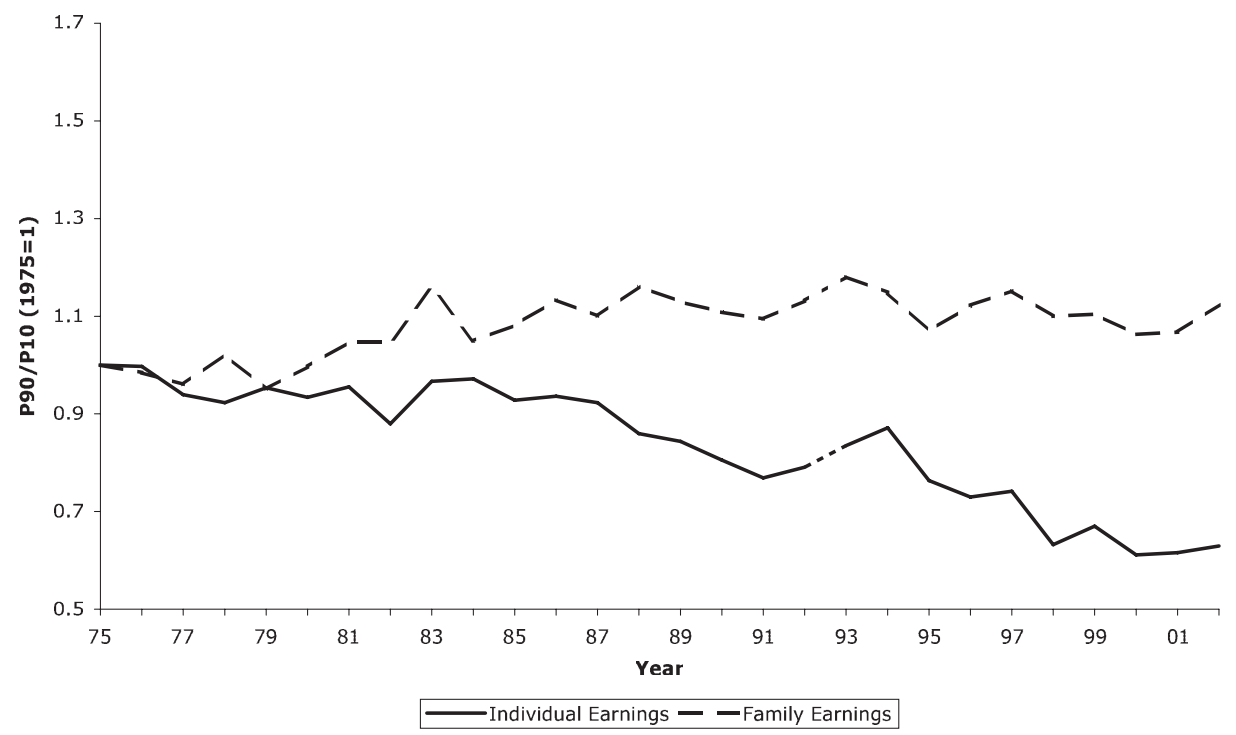

Figure 13. P90/P10 of Individual and Family Earnings: Females 22-62 with Positive Earnings $(1975=1.0)$

income concept from individual earnings to family earnings, we use the same sample used in the previous analysis. This avoids changes that are due solely to changes in sample composition.

Figures 12 and 13 plot inequality of individual earnings and family earnings for males and females, respectively. Figure 12 shows that including the earnings of 
other family members eliminates much of the cyclical swings in individual male earnings inequality. This is consistent with other family members increasing their hours to compensate for the cyclical reduction in earnings of males at the P10.

While family earnings inequality is less cyclically sensitive than individual earnings inequality for males, the two series show similar trends through 1990. Male individual earnings inequality declined from 1993 to 2000, while family earnings inequality remained roughly unchanged. After the recession that began in 2000, individual earnings inequality increased again. As a result of these changes, family earnings inequality was 51 percent higher in 2002 than in 1975, while male earnings inequality was 37 percent higher. Thus, including the earnings of other family members exacerbates the increased earnings inequality of males.

The difference in trends between individual earnings and family earnings inequality is also dramatic for females. Figure 13 shows that while female earnings inequality fell by 37 percent between 1975 and 2002, family earnings inequality for these females increased by 12 percent over the same period. This again reflects changes in earnings of other family members, primarily male spouses, for whom earnings inequality was increasing. While the P10 of family earnings increased by 36 percent between 1974 and 2002, the P90 increased by 53 percent. ${ }^{23}$ The fact that family earnings increased more for females at the top of the distribution of family earnings is in marked contrast to Figure 11 which shows that earnings increased more at the bottom of the distribution of individual earnings.

\section{Changes in Family Income Inequality}

Changes in the distribution of family earnings affect the distribution of family income, but can be offset or reinforced by changes in the level and distribution of other income sources. For example, the distribution of family income is affected by the distribution of capital income, as well as earnings. If capital income is increasingly concentrated in families with high-earnings, then the trend toward increased family earnings inequality will be amplified. ${ }^{24}$ Also, differential changes in family size by rank in the income distribution affect inequality of family income adjusted for family size even if income inequality is constant.

Figures 14 and 15 present the time series for the P90/P10 of family income (adjusted by the poverty line) for two different samples. Figure 14 continues to focus on our sample of workers 22 to 62 in order to isolate differences in inequality of family earnings and of family income, holding the sample constant. Figure 15 broadens the sample to include all persons living in families with a male or female head 22-62, including those headed by non-workers. ${ }^{25}$

In order to contrast differences in trends in inequality that reflect differences in income concept, not differences in samples, we start by contrasting changes in

\footnotetext{
${ }^{23}$ Data not shown.

${ }^{24} \mathrm{We}$ do not attempt to decompose the change in family income into its component parts because there are many ways to do so and there is no consensus on the most appropriate decomposition. For examples of two approaches, see Shorrocks (1983) and Cancian and Reed (1999).

${ }^{25}$ Note that this sample includes persons outside the age range of 22 to 62 who live in families where the head is in the age range. It also excludes some of the workers in the previous sample since those workers 22 to 62 living in families in which the head is not 22 to 62 are excluded.
} 


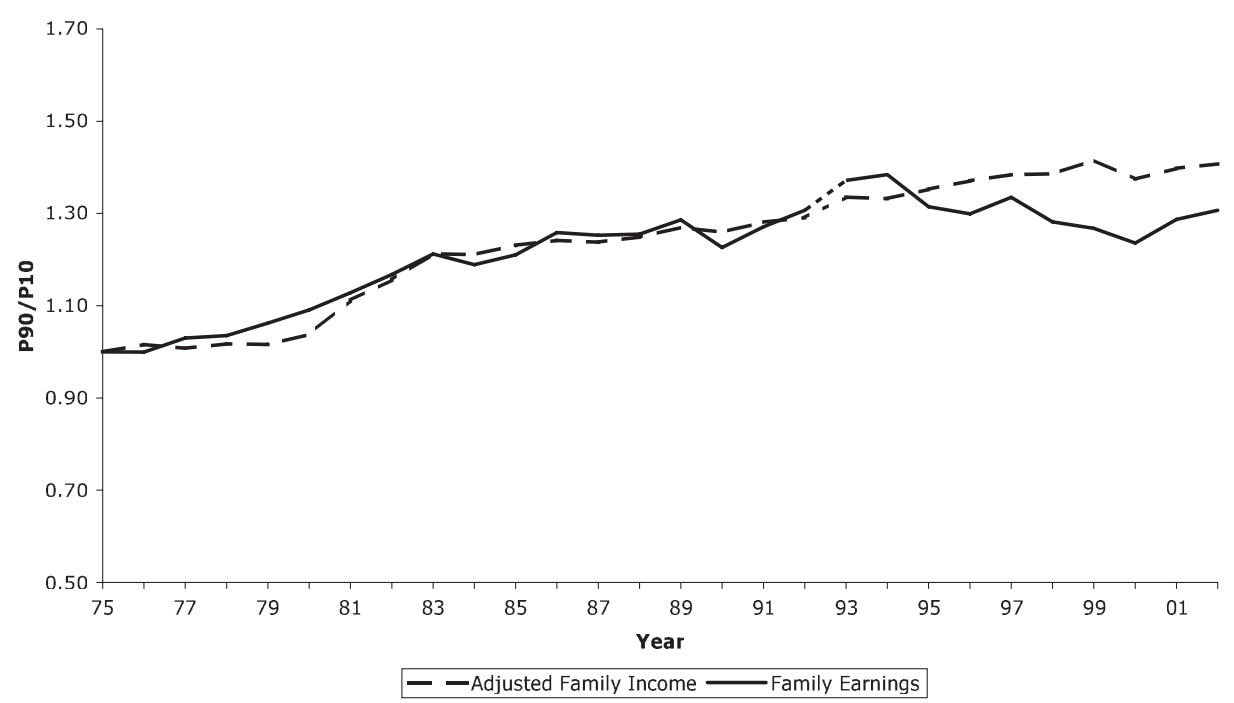

Figure 14. P90/P10 of Adjusted Family Income and Family Earnings for Male and Female Workers $22-62(1975=1.0)$

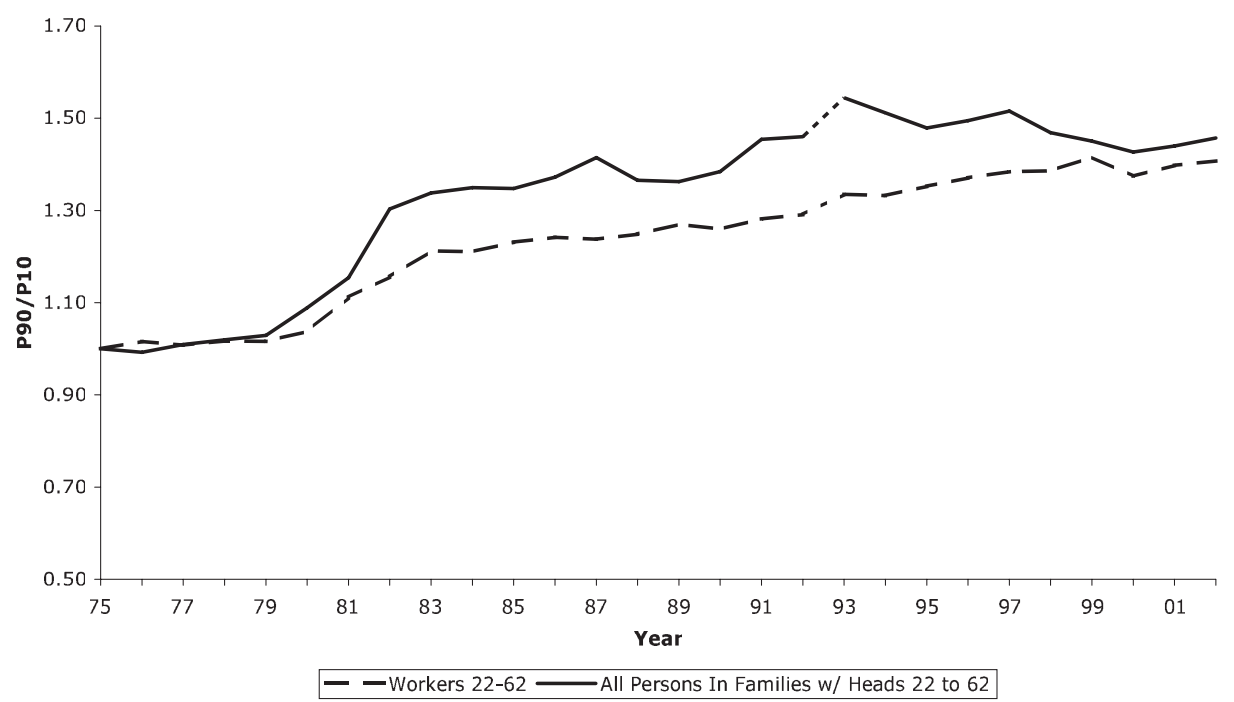

Figure 15. P90/P10 of Adjusted Family Income of All Persons vs. Persons in Families with Heads $22-62(1975=1)$

the P90/P10 of family income (adjusted by the poverty line) with changes in the P90/P10 family earnings for our sample of workers 22 to $62 .{ }^{26}$ Figure 14 shows that while family earnings inequality did not rise particularly rapidly during the

${ }^{26}$ Each family is weighed by the number of persons who meet this criterion. 
early 1980s for this sample, family income inequality did show substantial acceleration during this period when wage inequality of males was also growing rapidly (see Figure 4). Paradoxically, the changes in family income inequality in the early 1980s are more similar to changes in individual wage inequality than to changes in family earnings inequality, even though it is the latter that affects family income inequality directly. Family earnings, and family income inequality, however, closely mirror each other between 1985 and 1995.

Family income inequality and family earnings inequality again diverged after 1995. Inequality of family income (adjusted for family size) continued to increase at a moderate rate while family earnings inequality declined modestly. This implies that changes in the distribution of non-wage income and changes in family size were disequalizing after 1995 for these workers.

Figure 15 broadens the sample to include all persons rather than just workers. It, therefore, contrasts inequality of adjusted family income for all persons in families with a working age head (22 to 62) with the series for workers 22 to 62 shown in Figure 14. The striking difference in the two series is the even larger increase in family income inequality for this broader sample during the late 1970s and early 1980s. Between 1979 and 1982 family income inequality for all persons increased nearly 30 percent, while it increased by only 16 percent for workers, who have been the focus of our study thus far.

While wage inequality among males also accelerated during the late 1970s and early 1980s, the similarity in wage and family income inequality seems to be coincidental. If the acceleration in wage inequality during the early $1980 \mathrm{~s}$ had been the dominant factor behind the rapid rise in family income inequality of all persons during the same period, then we would have expected the change in wage inequality to translate into a similar rapid rise in family earnings inequality over the same period. This did not happen. Neither individual earnings nor family earnings inequality show a particularly rapid rise during the early 1980s.

Finally, we explore whether our results for family income inequality are sensitive to the method used to adjust for top-coding. Burkhauser et al. (2004) point out that using the P90/P10 of adjusted family income may not eliminate the effects of changes in the top coding even, if the top code for family income is above the P90 in all years. They propose an alternative method which we apply to our sample of all persons living in families with a head between the ages of 22 and 62. Figure 16 presents the P90/P10 using both methods. Their adjustment shows a steeper decline in the P90/P10 after 1995 than does the method we have used throughout this paper. However, their method continues to show a sharp increase in inequality during the early 1980 s. $^{27}$

One might have expected that changes in family income inequality were largely driven by changes in earnings inequality. However, family income inequality depends on the share of income coming from each income source and the correlations between sources, as well as inequality of each source. The fact that earnings of heads between the ages of 22 and 62 comprised only 56.7 percent of family income in 2002 indicates that other sources were important in

${ }^{27}$ We follow Burkhauser et al. (2004) in applying their method only to data starting in 1979. 


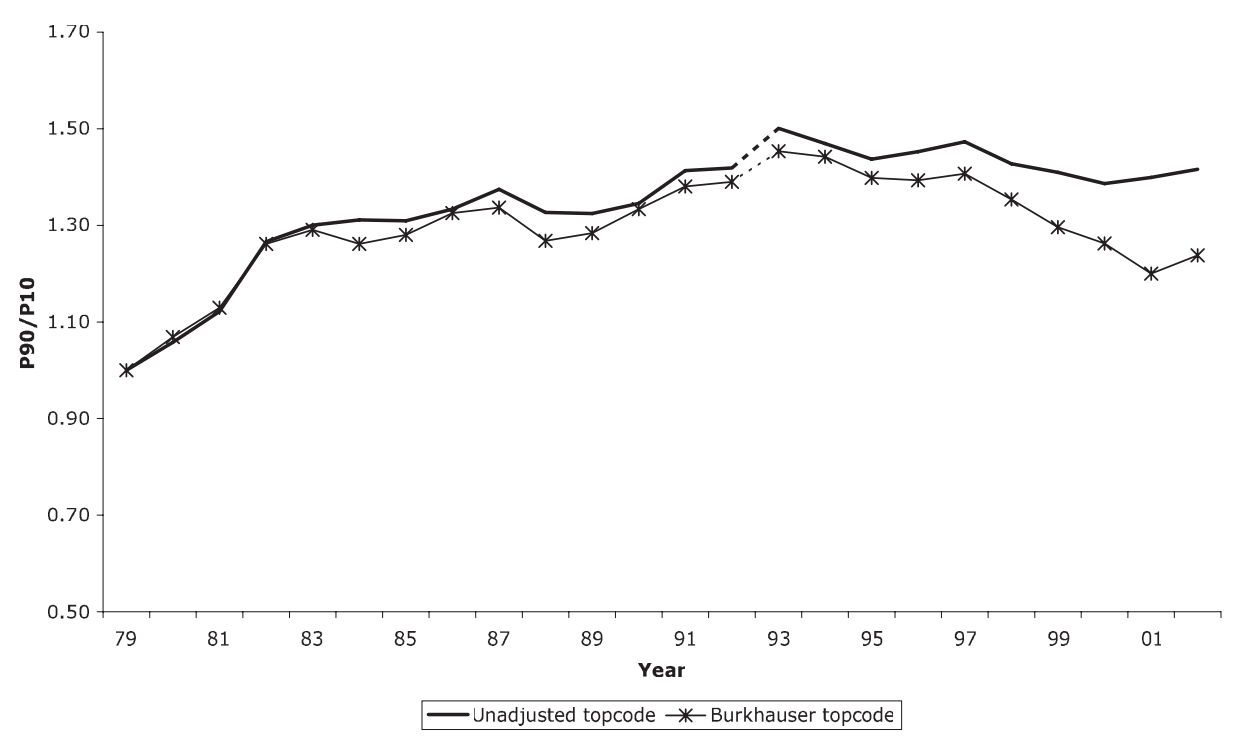

Figure 16. P90/P10 of Adjusted Family Income of All Persons in Families with Heads 22-62 $(1979=1.0)$

accounting for the level of family income inequality. ${ }^{28}$ Earnings of heads not only comprised a small proportion of family income but the proportion has been declining steadily. In 1975, 70.6 percent of family income came from heads earnings. By 2002 this proportion had declined 56.7 percent. Over the same period, earnings of other family members (primarily working wives) increased from 19.3 percent to 34.7 percent of family income; income from government cash transfers, property income (dividends, interest and rents) and other income sources remained roughly constant.

The next step in understanding the sources of change in family income inequality would be to decompose the change in overall inequality into its component parts, using accounting identities such as those proposed by Shorrocks (1983). Such identities would isolate the other important factors that accounted for changes in family income inequality. While these decompositions would not uncover the behavioral links between changes in wage inequality and changes in family income inequality, they would focus attention on those factors that need to be explained.

\section{Conclusions}

This paper documented changes over a quarter century in inequality of four income concepts, using consistent definitions and samples across concepts. We have focused on four conceptually distinct distributions: the distribution of wage

\footnotetext{
${ }^{28}$ Total family income/needs is decomposed into earnings of heads, earnings of others, property income, government cash transfers, and other sources of income for our sample of persons in families with a head 22 to 62 . Data available on request.
} 
rates, individual earnings, family earnings and family income adjusted for family size. Labor economists have tended to focus on changes in the distribution of wage rates, the most restrictive income concept, since they are interested in changes in market and institutional forces that have altered the prices paid to labor of different types. At the other extreme, policy analysts have focused on changes in the distribution of the broadest income concept, family income adjusted for family size. This reflects their interest in changes in resources available to different groups, including the poor.

We showed that male wage inequality and inequality of family income closely mirror each other. Both series grew rapidly during the late 1970s and early 1980s and then continued to grow, but at a slower rate until the early 1990s. After that point both series remained high but stopped growing.

The similar patterns in these two series, however, do not necessarily mean that increased male wage inequality was the primary factor leading to increases in family income inequality. We showed that there were other large, but offsetting factors, affecting family income inequality. While male wage and earnings inequality increased through the early 1990s, female wage inequality actually declined steadily from 1975 through 2002.

While earnings inequality of males grew even more rapidly than wage inequality during the early 1980s, this largely reflects cyclical changes in hours. For females, changes in hours more than offset the rise in wage inequality. The acceleration in male wage and earnings inequality during the early 1980 s disappears when earnings of other family members are included. Thus, changes in work hours by other family members seems to have largely offset increased male labor market inequality.

It is only when we further broaden the definition to family income that the acceleration in inequality during the early 1980s reappears. The similarity of the time series of male wage inequality and family income inequality, however, seems to be coincidental. While we do not fully understand why family income inequality also increased rapidly during the early 1980s it seems likely that one should look beyond factors that were causing male wage inequality to accelerate.

\section{REFERENCES}

Burkhauser Richard, J. Butler, Shuaizhang Feng, and Andrew Houtenville, "Long Term Trends in Earnings Inequality: What the CPS Can Tell Us," Economic Letters, 82, 295-9, 2004.

Burtless Gary and Christopher Jencks, "American Inequality and Its Consequences," in H. J. Aaron, J. M. Lindsay, and P. S. Nivola (eds), Agenda for a Nation, Brookings Institution, Washington, D.C., 2003.

Cancian, Maria and Deborah Reed, "The Impact of Wives' Earnings on Income Inequality: Issues and Estimates," Demography, 36(3), 173-84, 1999.

Card, David and John DiNardo, "Skill-Biased Technological Change and Rising Wage Inequality: Some Problems and Puzzles," Journal of Labor Economics, 20, 733-83, 2002.

Danziger, Sheldon and Peter Gottschalk, America Unequal, Harvard University Press, Cambridge, MA, Russell Sage Foundation, New York, NY, 1995.

Gottschalk, Peter, "Inequality, Income, Growth, and Mobility: The Basic Facts," Journal of Economic Perspectives, 11, 21-40, 1997.

Greenstein, Robert and Isaac Shapiro, "The New Definitive CBO Data on Income and Tax Trends," mimeo, Center on Budget and Policy Priorities, Washington, D.C., 2003. 
Johnson George and Frank Stafford, "The Labor Market Implications of International Trade," in O. Ashenfelter and D. Card (eds), Handbook in Labor Economics, vol 3B, North Holland, Amsterdam, 1999.

Katz, Lawrence and Kevin Murphy, "Changes in Relative Wages, 1963-1987; Supply and Demand Factors," Quarterly Journal of Economics, 107, 35-78, 1992.

Katz, Lawrence and David Autor, "Changes in the Wage Structure and Earnings Inequality," in O. Ashenfelter and D. Card (eds), Handbook in Labor Economics, vol 3A, North Holland, Amsterdam, 1999.

Lee, David, "Wage Inequality in the U.S. During the 1980s: Rising Dispersion or Falling Minimum Wage," Quarterly Journal of Economics, 114(4), 1999.

Lemieux, Thomas, "Increased Residual Wage Inequality: Composition Effects, Noisy Data, or Rising Demand for Skill?” Working Paper 69, University of California, Berkeley, 2004.

Shorrocks, Anthony F., "The Impact of Income Components on the Distribution of Family Incomes," Quarterly Journal of Economics, 98, 311-26, 1983.

Stewart, Kenneth J. and Stephen B. Reed, "Consumer Price Index Research Series Using Current Methods, 1978-1998,” Monthly Labor Review, 122, 29-38, 1999. 